DOI https://doi.org/10.36059/978-966-397-117-9/75-96

\title{
THE HUMAN RIGHT TO PROFESSIONAL LEGAL ASSISTANCE IN UKRAINE: CONCEPT AND LEGAL NATURE
}

\section{Dzhuska A. V.}

\section{INTRODUCTION}

Recognition of any state democratic, social and legal is impossible without creating an effective system of protection of fundamental human rights and freedoms in it. A special place in this system is the right to professional legal assistance.

The topicality of the research of human right to professional legal assistance in Ukraine is especially reinforced by the constitutional and legal reform which was introduced in 2016 in the area of justice. In accordance with the amendments to the Constitution of Ukraine, everyone has the right to professional legal assistance. In cases provided for by law, this assistance is provided free of charge. Everyone is free in choosing a defender of one's rights (Article 59). Article $131^{2}$ of the Constitution of Ukraine states that an attorney provides professional legal assistance in Ukraine. Independence of the attorney is guaranteed. The principles of the organization and activity of the advocacy and practice of law in Ukraine are determined by law. The attorney exclusively represents the other person in court, as well as protection from criminal charges. In addition, the law may specify exceptions for representation in a court in labor disputes, disputes concerning the protection of social rights, elections and referendums, minor disputes, as well as in relation to the representation of minors or infants and persons recognized as incapacitated by the court or whose capacity is limited ${ }^{1}$.

First of all, ensuring the right to professional legal assistance is not only the constitutional and legal obligation of the state, but also the observance of international legal obligations undertaken by Ukraine in accordance with the provisions of the United Nations Universal Declaration of Human Rights (1948), the International Covenant on Civil and Political Rights (1966) as the basic documents containing universal

\footnotetext{
1 Конституція України від 28.06.1996 p. № 254к/96-BP. URL: http://zakon5.rada.gov.ua/ laws/show/254\%D0\%BA/96-\%D0\%B2\%D1\%80.
} 
standards of human rights, as well as the Convention for the Protection of Human Rights and Fundamental Freedoms (1950) is a basic document of a regional nature (its effect extends to the member states of the Council Europe).

In addition to the Constitution as the Basic Law and international treaties in the field of human rights, the issue of ensuring the right to professional legal assistance is regulated by decisions of the Constitutional Court of Ukraine, the European Court of Human Rights, as well as other normative legal acts (codes, laws, by-laws, in particular, procedural codes, the Laws of Ukraine "On the Bar and Practice of Law" of July 5, 2012, No. 5076-VI, "On the Judiciary and the Status of judges" of June 2, 2016, No. 1402-VIII, "On the Notary" of September 2, 1993, No. 3425-XII, "On Free Legal Aid" of June 2, 2011, No. 3460-VI, etc.).

It should be noted that, unfortunately, at the legislative level the definition of the concept of the right to professional legal assistance is not defined, which increases the relevance of the chosen subject and necessitates the doctrinal interpretation of this concept.

\section{Definition of the concept "human right to professional legal assistance"}

Researching the decisions of the Constitutional Court of Ukraine we have found that they contain only provisions regarding the right to legal assistance. Thus, in the decision of the Constitutional Court of Ukraine (case about the right to legal assistance) of September 30, 2009, No. 23-rp/2009, it was specified that the right to legal assistance is a guaranteed possibility of every person to receive such assistance in the amount and in the forms determined it, regardless of the nature of the legal relationship of a person with other subjects of $\operatorname{law}^{2}$. And in the decision of the Constitutional Court of Ukraine (case about the right to choose a lawyer) of November 16, 2000, No. 13-rp/2000 it is stated that the right to legal assistance is the possibility of an individual to receive legal services guaranteed by the Constitution of Ukraine ${ }^{3}$.

\footnotetext{
${ }^{2}$ Рішення Конституційного Суду України у справі за конституційним зверненням громадянина Голованя Ігоря Володимировича щодо офіційного тлумачення положень статті 59 Конституції України (справа про право на правову допомогу) від 30.09.2009 р. № 23-рп/2009. Офіuійний вісник Украӥни. 2009. № 79. Ст. 62.

${ }^{3}$ Рішення Конституційного Суду України у справі за конституційним зверненням громадянина Солдатова Геннадія Івановича щодо офіційного тлумачення положень статті 59 Конституції України,
} 
The Explanatory note of January 26, 2016, to the Draft Law of Ukraine "On Amendments to the Constitution of Ukraine (Regarding Justice)" of November 25, 2015, No. 3524 states that the right to professional legal assistance is guaranteed by the Basic Law of the State the person's ability to receive high-quality legal services that can only be provided by a professional attorney who has undergone special training and not by another person. At the same time, the proposed formula does not deny the right to legal assistance in general, including the free assistance, which can be provided by another (except for professional attorneys) lawyers. However, emphasis is placed on the assurance received by the person of professional assistance ${ }^{4}$.

In general, the right to professional legal assistance can be interpreted objectively and subjectively:

- in an objective sense, it is a set of legal norms regulating relations on the provision of professional legal assistance;

- in a subjective sense, it is the person's ability to provide or receive professional legal assistance in order to ensure the rights, freedoms and legitimate interests of the person in need of such assistance is guaranteed by the Constitution of Ukraine and other normative-legal acts 5 .

The content of the subjective right of a person to professional legal assistance can be expressed through the following powers: 1) the ability to personally take actions aimed at the implementation of the relevant right (right to own actions), including access to power subjects (international, national) for protection (compulsory security) one's rights; 2) the possibility to abstain from committing certain actions for the realizing one's rights; 3 ) the ability to demand from other persons proper conduct (the right to other actions or legal proceedings), including for the purpose of enforcing the implementation of the corresponding rights; 4) the possibility to apply to socially obligated persons for the provision of

статті 44 Кримінально-процесуального кодексу України, статей 268, 271 Кодексу України про адміністративні правопорушення (справа про право вільного вибору захисника) від 16.11.2000 р. № 13-рп/2000. Офіиіийний вісник України. 2000. № 47. Ст. 109.

4 Пояснювальна записка від 26.01.2016 p. до проекту Закону України про внесення змін до Конституції України (щодо правосуддя) від 25.11.2015 p. № 3524. URL: http://w1.c1.rada.gov.ua/pls/ zweb2/webproc4_1?pf3511=57209.

5 Литовченко Л. А., Чуйко О. В. Поняття “право на правову допомогу” та "правова допомога" у контексті конституційного та цивільно-процесуального законодавства. Науковий вісник Дніпропетровського державного університету внутрішніх справ. 2011. № 4. С. 159-160. 
certain material and other goods for the satisfaction of spiritual and social needs ${ }^{6}$.

In our opinion, the human right to professional legal assistance can be considered: 1) firstly, as a separate constitutional right (Article 59 of the Constitution of Ukraine), which can not be limited (second part of the Article 64 of the Constitution of Ukraine), and secondly, as a constitutional guarantee for the implementation, protection of other constitutional human rights and freedoms guaranteed by Articles 29, 4056, 61, 63 of the Constitution of Ukraine, and thirdly, as a derivative of the constitutional right to information (Article 34 of the Constitution of Ukraine), constitutional law to judicial protection of human rights and freedoms (part one of the Article 55 of the Constitution of Ukraine) and the constitutional right to respect for the dignity of a person (part one of the Article 28 of the Constitution of Ukraine); fourthly, as a mechanism for mediating the relations between the state, society and a person, which is realized in the most important spheres public life by providing appropriate benefits. The peculiarity of the right to professional legal assistance lies in the fact that it mediates relations not only between people, but with the state as a whole; 2) as a complex-component right, the structure of which includes: the right to apply to an attorney for obtaining professional legal assistance for the purpose of the effective implementation, protection of rights, freedoms and legal interests of a person; the right to certain content and quality of received (provided) professional legal assistance; the right to receive legal aid on a free basis in the manner prescribed by law; the right to demand the appropriate active and effective actions from an attorney; the right to information about the possibility of obtaining professional legal assistance, including free of charge; the right to receive professional legal assistance in an accessible and comprehensible language and in a convenient form; the right to demand protection of the violated right; 3 ) as the most important element that reveals the content of such a basis of the constitutional order, as the legal nature of the state (Article 1 of the Constitution of Ukraine).

As noted above, the human right to professional legal assistance is derived from the right to information. The basis for the right to professional legal assistance is the fundamental social benefits (legal

\footnotetext{
${ }^{6}$ Ісакова В. М. Право на правову допомогу: поняття, особливості, гарантії: автореф. дис. ... канд. юрид. наук. Харків, 2013. C. 10-11.
} 
information and protection of human rights, freedoms and legitimate interests). Therefore, when realizing the right to professional legal assistance, a person receives from an attorney the necessary legal information for the purpose for effective protection of one's rights, freedoms and legitimate interests.

Also, it should be noted that the right to professional legal assistance is a constitutional right, since it is guaranteed by the Constitution of Ukraine (Article 59 of Chapter II "Rights, Freedoms and Responsibilities of a Person and a Citizen").

\section{The essence of the human right to professional legal assistance}

It is necessary to disclose the essence of the concept "professional legal assistance" when researching the legal nature of the human right to professional legal assistance.

A key element of professional legal assistance is the concept "help". Help is a kind of human activity, one of the types of social interaction, one of the forms of social assistance. It represents a type of relationship between actors in which one subject acts in the interests of another to achieve the result of another useful for another subject ${ }^{7}$.

The signs of "professional" and "legal", which are added to the concept "help", indicate that this type of activity (assistance) is provided by an attorney (a person of the legal profession, who has the necessary level of professional training, is bound by the rules of professional (lawyer) ethics, legal requirements for access to the profession and bear responsibility for improper performance of one's professional duty $)^{8}$.

The term "legal assistance" is used in international law and in the law of certain states which can be interpreted differently.

Thus, there is an extended interpretation of the concept of "the right to legal assistance" within the United Nations standards. "The Basic Principles on the Role of Lawyers" (adopted by the Eighth United Nations Congress on the Prevention of Crime and the Treatment of Offenders, Havana, Cuba 27 August to 7 September 1990) contain the following provisions: all persons are entitled to call upon the assistance of a lawyer

\footnotetext{
${ }^{7}$ Панченко В. Ю. Юридическая помощь (вопросы общей теории): монография. Красноярск: Сиб. федер. ун-т, 2011. С. 19, 22.

8 Пояснювальна записка від 26.01.2016 p. до проекту Закону України про внесення змін до Конституції України (щодо правосуддя) від 25.11.2015 p. № 3524. URL: http://w1.c1.rada.gov.ua/pls/zweb2/webproc4_1?pf3511=57209.
} 
of their choice to protect and establish their rights and to defend them in all stages of criminal proceedings (paragraph 1); governments shall ensure the provision of sufficient funding and other resources for legal services to the poor and, as necessary, to other disadvantaged persons. Professional associations of lawyers shall cooperate in the organization and provision of services, facilities and other resources (paragraph 3); advising clients as to their legal rights and obligations, and as to the working of the legal system in so far as it is relevant to the legal rights and obligations of the clients (subparagraph (a) of paragraph 13); assisting clients in every appropriate way, and taking legal action to protect their interests (subparagraph (b) of paragraph 13); assisting clients before courts, tribunals or administrative authorities, where appropriate (subparagraph (c) of paragraph 13$)^{9}$. Therefore, the term "legal assistance" combines various types of legal assistance (services), both free of charge and payable.

In accordance with the Resolution (78) 8 "On legal aid and advice" (adopted by the Committee of Ministers of the Council of Europe on 2 March 1978 at the 284th meeting of the Ministers' Deputies), the concepts "legal aid" and "legal advice" have different meanings. This document states: no one should be prevented by economic obstacles from pursuing or defending his right before any court determining civil, commercial, administrative, social or fiscal matters. To this end, all persons should have a right to necessary legal aid in court proceedings. When considering whether legal aid is necessary, account should be taken of: a. a person's financial resources and obligations; b. the anticipated cost of the proceedings (paragraph 1); legal aid should provide for all the costs necessarily incurred by the assisted person in pursuing or defending his legal rights and in particular lawyers' fees, costs of experts, witnesses and translations. It is desirable that, where legal aid is granted, there should be an exemption from any requirement for security for costs (paragraph 3 ); the state should ensure that a person in an economically weak position should be able to obtain necessary legal advice on all questions arising out

\footnotetext{
${ }^{9}$ Basic Principles on the Role of Lawyers (adopted by the Eighth United Nations Congress on the Prevention of Crime and the Treatment of Offenders, Havana, Cuba 27 August to 7 September 1990). URL: https://www.ohchr.org/en/professionalinterest/pages/roleoflawyers.aspx
} 
of the matters mentioned in principle 1, which may affect his rights or interests (paragraph 12) ${ }^{10}$.

Like the law of the Council of Europe, the issue of legal assistance in Germany is solved by the Law on Assistance in the Payment of Procedural Costs of 1980 and the Law on Legal Advice and Representation of People with Low Income since 1994. Moreover, such assistance in Germany is only the means to bear all procedural costs, both forensic and non-judicial, including for the payment of a lawyer's services during the preparation of a case for trial and in court proceedings. Another subsystem of such assistance in Germany is the legal services provided under the relevant provisions of the German Civil Code (BGB) of 1896. Their peculiarity is that in the event of these relations, the equality of their parties is presumed, which is the basic principle of civil legal relations.

French legislation on the provision of legal assistance is fully in line with the position of the United Nations in this matter. In France, legal assistance is: 1) free legal aid; 2) assistance in facilitating access to legal protection: a. providing individuals with general information about their rights and responsibilities, as well as directing persons to organizations responsible for the realization of their rights; b. assistance in the implementation of all measures aimed at the realization of the rights of a person or the fulfillment of legal obligations, as well as assistance in the implementation of extrajudicial procedures; c. legal advice; d. assistance in the compilation and conclusion of legal acts; 3) mediation of a lawyer during detention; 4) assistance in the consideration and resolution of criminal cases.

Legislation of Norway under the legal aid understands only free aid, in particular: legal advice; judicial assistance; exemption from litigation costs.

In England such assistance means different types of legal services that are provided to individuals free of charge. In particular, they have: legal advice; legal support; representation ${ }^{11}$.

Considering the interpretation of the concept of legal assistance in the laws of Germany, France, Norway and England we see that a model of

\footnotetext{
${ }^{10}$ Resolution (78) 8 "On legal aid and advice" (adopted by the Committee of Ministers of the Council of Europe on 2 March 1978 at the 284th meeting of the Ministers' Deputies). URL: https://www.euromedjustice.eu/en/system/files/20090128115013_res\%2878\%298eCoE.pdf

${ }^{11}$ Правова допомога: зарубіжний досвід та пропозиції для України / авт.-упоряд. О. А. Банчук, М. С. Демкова. Київ: Факт, 2004. С. 11-13.
} 
legal assistance implemented in the legislation of France is the most acceptable for Ukraine.

It should be emphasized that in Ukraine exemption from litigation costs is a separate institution of procedural law and does not apply to legal assistance.

It should be noted that there are different approaches (on different grounds) in the legal literature that help characterize the notion of professional legal assistance.

In our opinion, depending on the content and purpose of the activity in the field of law (legal sphere), it is expedient to consider professional legal assistance through the concept "ensuring rights" as the broadest, since it is not limited by implementation or protection.

The professional legal assistance as an ensuring of human rights is a system of measures aimed at the realization and protection of the rights, freedoms and legal interests of an individual, which are implemented by an attorney, and are aimed at achieving full legal protection. At the same time, in the provision of law, a special place is taken in such a way as promotion.

The main features of professional legal assistance, which characterize it as a concept, can be divided into: a. signs of subjects; b. signs of the object; c. structural and informative features (purpose, means, results, interests) ${ }^{12}$.

Signs of subjects. The professional legal assistance as an activity takes place within the framework of relations between the subject of the receipt and the subject of provision. The subject of obtaining professional legal assistance is primarily a person (an individual), and the subject of provision (an attorney).

The inability of the subject to realize one's rights, freedoms and legitimate interests by own actions necessitates the provision of professional legal assistance. Such assistance must arise due to the lack of special knowledge and skills in the field of law (ignorance of the rights in one or another life situation, legal means of their implementation, etc.), the existence of legal and/or factual obstacles to the independent realize of legal capacity (incapacity, age, state of health, unwillingness, psychological unwillingness to act by yourself in the legal field, etc.).

\footnotetext{
12 Панченко В. Ю. Юридическая помощь (вопросы общей теории): монография. Красноярск: Сиб. федер. ун-т, 2011. С. 102.
} 
The interest of the person, initiative, and the appeal for help is a prerequisite for the provision of professional legal assistance.

The professional legal assistance, as a rule, can not be provided contrary to the will of the subject of obtaining. But there are exceptions to the rules. For example, the legislation of Ukraine establishes a list of cases where the participation of an attorney is mandatory (Article 52 of the Criminal Procedural Code of Ukraine).

The subject of the provision of professional legal assistance in the organizational and structural plan is a person acting in accordance with the procedure established by law, and doing this type of professional activity. The subject of the provision of professional legal assistance is an attorney, that is, an individual who is subject to very serious professional requirements (the presence of complete higher legal education, possession of the state language, the presence of work experience in the field of law of not less than two years, passing a qualifying examination, undergoing internship (except in cases established by the Law of Ukraine "On the Bar and Practice of Law"), the swearing an oath of an attorney of Ukraine and obtaining a certificate on the right to practice of law ${ }^{13}$.

It is worthwhile to focus on such a concept as the qualification of a person who provides legal assistance (in particular, it will be a question of attorneys and other lawyers).

The qualification of the person providing legal assistance is, first of all, the degree and type of professional education of the subject of such assistance, the presence of one's knowledge, skills and abilities necessary for its implementation. In this aspect, a sign of qualification is associated with the characteristics of the subject of the provision, which is confirmed by official documents (on education, experience in the field of law, etc.). Qualification is the external aspect of legal assistance, which reflects the state of the subject of its provision. In a dynamic, meaningful plan qualification means a measure of quality, the level of the activity oneself, its characteristics, depending on complexity, accuracy, responsibility, compliance with laws, requirements, rules of optimal use of means, methods of assistance in each case ${ }^{14}$.

\footnotetext{
13 Про адвокатуру та адвокатську діяльність: Закон Украӥни від 05.07.2012 р. № 5076-VI. Відомості Верховної Ради України. 2013. № 27. Cm. 282; Панченко В. Ю. Юридическая помощь (вопросы общей теории): монография. Красноярск: Сиб. федер. ун-т, 2011. С. 103-104.

${ }^{14}$ Панченко В. Ю. Юридическая помощь (вопросы общей теории): монография. Красноярск: Сиб. федер. ун-т, 2011. С. 104-105.
} 
The qualification of legal assistance covers two aspects: the qualification (professionalism) of the subject of provision (and in this sense is a feature that characterizes the subject of provision) and the quality of the assistance (this is already a sign of the activity oneself, its structure and content). Before the actual provision of legal assistance, it is not possible to say whether it is qualified or not. Therefore, the concept of "legal assistance" and "qualified legal assistance" relate both to the generic and specific notion ${ }^{15}$.

In addition, legal assistance must be effective in line with international practice. The requirement for the effectiveness of legal assistance involves the introduction of a special term "minimum standards for qualified legal assistance", among which: the legal education of the person providing the assistance; presentation of special requirements (qualification exam, internship, etc.) to a person who provides certain types of legal assistance; activity of providing legal assistance ${ }^{16}$.

The European Court of Human Rights has repeatedly stated the violation of the right to protection in cases where the defender was formally appointed, but did not effectively protect. Indicative is the judgment of the European Court of Human Rights (Yaremenko v. Ukraine of June 12, 2008), in which each of the two defenders representing the applicant saw him only once and only during the interrogation, and none of them interrogated he did not see the applicant, indicating the symbolic nature of their services. In this case, the Court questioned the protection of the applicant's effective defense ${ }^{17}$.

The professional legal assistance provided by the attorney, poorly, without reason, can not be called qualified. And this is a serious problem, especially when it comes to the protection of criminal prosecution. Unfortunately, in Ukraine there are no tools that fully guarantee the quality of attorneys' services, especially those who provide free secondary legal aid. The low quality of the assistance provided can be explained by the low level of services provided by the attorneys providing free

\footnotetext{
15 Панченко В. Ю. Юридическая помощь (вопросы общей теории): монография. Красноярск: Сиб. федер. ун-т, 2011. С. 108.

16 Мельниченко Р. Г. Конституционное право на юридическую помощь: автореф. дис. ... канд. юрид. наук. Волгоград, 2001. С. 13.

17 Степанова С. В. Ефективна допомога захисника як складова конституційного права на професійну правничу допомогу та міжнародний стандарт права на справедливий суд. Юриспруденція у формуванні правової держави та громадянського суспільства: матеріали міжнарод. юрид. наук.-практ. Інтернет-конф. $\quad(06.10 .2016$ p.). URL: http://legalactivity.com.ua/index.php?option=com_content\&view= article\&id=1332\%3A041016-20\&catid=161\%3A2-1016\&Itemid=201\&lang=ru.
} 
secondary legal aid, which is directly dependent on public funding. Therefore, the state is obliged to create certain conditions for the implementation of the human right to professional legal assistance, given that such assistance should be real, professional and qualified. At this time, the first steps have been taken to create such conditions. In particular, it refers to the adopted Law of Ukraine "On the Bar and Practice of Law" and the Lawyer's Ethics Rules, which set up quite serious professional requirements for the profession of attorneys. Thus, the state fully shares the responsibility for the professionalism of the assistance of attorneys ${ }^{18}$.

If professional legal assistance is provided by an attorney in violation of the rules of law (in particular, the Law of Ukraine "On the Bar and Practice of Law") and/or norms of professional ethics (the Lawyer's Ethics Rules), then such assistance may be considered unqualified.

We note the fact that the norm of the Article 59 of the Constitution of Ukraine guarantees everyone the right to professional legal assistance, but there is no question of qualification in it. It can be assumed that the legislator, when replacing the concept of "legal assistance" with the term "professional legal assistance" in the Basic Law, meant that the sign "professional" would mean that such assistance would be provided by a qualified person of the attorney profession.

Signs of the object. The object of professional legal assistance is a problematic legal situation, that is, the problematic life situation of the subject of its receipt, which has a legal character. In this case, under the problematic legal situation is understood complex life circumstances (conflict or state in the relations of people threatening the conflict), on the outside (dispute, divergence of interests, rivalry of thoughts and intentions, which requires the legal solution) $)^{19}$.

The problematic legal situation as an object of professional legal assistance is characterized by the fact that:

- this is the life situation of a person which exists as objective (in quantitative terms, the totality of social, first of all, legal, relations, factors and circumstances), as well as that which exists in one's consciousness;

18 Степанова С. В. Ефективна допомога захисника як складова конституційного права на професійну правничу допомогу та міжнародний стандарт права на справедливий суд. Юриспруденція у формуванні правової держави та громадянського суспільства: матеріали міжнарод. юрид. наук.-практ. Інтернет-конф. (06.10.2016 p.). URL: http://legalactivity.com.ua/index.php?option=com_content\&view= article \&id=1332\%3A041016-20\&catid=161\%3A2-1016\&Itemid=201\&lang=ru.

${ }^{19}$ Алексеев С. С. Восхождение к праву. Поиски и решения. Москва: Норма, 2001. С. 256-259. 
- the situation hinders the use of legal possibilities (rights, freedoms, legitimate interests), making it difficult to realize the various interests of the person receiving professional legal assistance;

- the legal nature of the life situation is conditioned by the presence of real or predictable social ties in the field of legal regulation and the necessity of its solution by means of a legal nature;

- the problematic nature of the legal situation is caused by the inability of the person to transform it (to resolve it) through the independent realize of the rights, freedoms and legitimate interests which are due to $\mathrm{it}^{20}$.

Structural and content signs. Professional legal assistance is a promotion that is carried out in the interests of another person. Like all other social needs of a person, the need for such assistance arises when its satisfaction is a means of realizing a particular interest ${ }^{21}$. The realization of the interests of another person is the main process in respect of which professional legal assistance has an "auxiliary" character, the course of which it facilitates, supports. Specific for such assistance is that the realization of interests takes place in the legal field, in public relations, which constitute the subject of legal regulation (in the problematic legal

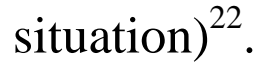

The important feature of professional legal assistance as a form of assistance is the priority of the rights, freedoms and legitimate interests of a person receiving such assistance to meet one's individual interests ${ }^{23}$. Note that in the first part of the Article 28 of the Law of Ukraine "On the Bar and Practice of Law" it is indicated that "an attorney, attorney bureau or attorney company shall not enter into the contract on provision of legal services in the event of conflict of interest" ${ }^{\prime 24}$.

The professional legal assistance is the purposeful activity. The main objectives of professional legal assistance include: ensuring the rights, freedoms and legitimate interests of the individual, achieving maximum

\footnotetext{
${ }^{20}$ Панченко В. Ю. Юридическая помощь (вопросы общей теории): монография. Красноярск: Сиб. федер. ун-т, 2011. С. 111-112.

21 Михайловская И. Б., Кузьминская Е. Ф., Мазаев Ю. Н. Юридическая помощь населению: потребности и возможности. Москва. 1995. С. 8.

${ }^{22}$ Панченко В. Ю. Юридическая помощь (вопросы общей теории): монография. Красноярск: Сиб. федер. ун-т, 2011. С. 115.

23 Панченко В. Ю. Юридическая помощь (вопросы общей теории): монография. Красноярск: Сиб. федер. ун-т, 2011. С. 122.

24 Про адвокатуру та адвокатську діяльність: Закон України від 05.07.2012 р. № 5076-VI. Відомості Верховної Ради України. 2013. № 27. Сm. 282
} 
degree of one's security; provision of a favorable human life; creating a person with legal means favorable conditions for the protection of one's subjective rights; protection of human rights, etc. Undoubtedly, professional legal assistance, acting as a legal guarantee of the rights and freedoms, is an important element of the mechanism of ensuring the rights and freedoms of individual and citizen and in the system with other legal means working to achieve their full realization ${ }^{25}$.

The main objective of professional legal assistance is to maximize the full realization of the rights, freedoms and legitimate interests of the subjects interested in it by transforming (overcoming or preventing) a specific problematic legal situation $^{26}$.

At the same time, it should be noted that the provision of paid professional legal assistance (on a contractual basis) does not guarantee the receipt of a positive result in the case in favour of the client. Therefore, paid professional legal assistance has a risk (aleatory) character.

The content of professional legal assistance consists of actions using the means of a legal nature, which are carried out by the subject of such assistance (attorney), on the grounds and in a manner not prohibited by the Constitution and laws of Ukraine. If such assistance is out of the law, then it can not be granted. This content of assistance gives it the property of "legality", the legal nature, which consists in the predominant use of legal means to achieve goals, the establishment, change and termination of legal relations, that is, to obtain a legal result ${ }^{27}$. Such assistance can be: provision of legal information, consultations and legal clarifications, statements, complaints, procedural and other documents of a legal nature, representation of the interests of a person in courts, other state bodies, local self-government bodies, other persons, provision protecting a person from prosecution, providing a person with assistance in securing access to secondary legal assistance and mediation ${ }^{28}$. In addition, the commission of actions (services) that constitute professional legal assistance may have

\footnotetext{
${ }^{25}$ Панченко В. Ю. Юридическая помощь (вопросы общей теории): монография. Красноярск: Сиб. федер. ун-т, 2011. С. 125.

26 Панченко В. Ю. Юридическая помощь (вопросы общей теории): монография. Красноярск: Сиб. федер. ун-т, 2011. С. 127; Андрусів В. Г. Співвідношення забезпечення адвокатурою права на захист 3 наданням правової допомоги. Бюлетень Міністерства юстищї Украӥни. 2006. № 12 (62). С. 130.

27 Жалинский А. Э. Основы профессиональной деятельности юриста. Введение в специальность. Смоленск: Изд-во Смол. ун-та, 1995. С. 14-15.

28 Закон України "Про безоплатну правову допомогу". Науково-практичний коментар / за заг. ред. М. В. Оніщука. Київ: КП-Сервіс, 2012. С. 11.
} 
the meaning of a legal fact (events, actions, state) that generates, modifies or terminates a specific legal relationship. For example, after having filed a lawsuit with an attorney and lodging it with a court (a legal fact), the person acquires the status of participant in the trial (there are certain legal consequences, there is a legal relationship). Otherwise, for example, legal information or counseling carried out by a lawyer does not cause legal consequences when the received legal information remains only in the consciousness of the person which receives professional legal assistance.

The professional legal assistance (as well as any activity) has two sides: external (objective) - external actions of the subject of assistance, aimed at transforming (overcoming) the problematic legal situation, and internal (subjective) - mental activity of the subject of the assistance (this consideration goes beyond the scope of this research).

The subject of provision of professional legal assistance while doing certain acts for the interests of the recipient of the assistance uses legal means (means of demeanours and means of doing (technologies)) through which the interests of the subjects of law are met, socially useful goals are achieved. Since professional legal assistance is an action taken by the subject of provision in the interest of the subject of receiving the assistance, then it (professional legal assistance) is a mean of doing.

It should be noted that legal means used in the provision of professional legal assistance include legal advice and counseling. The subject provides professional assistance to the subject of obtaining legal assistance to choose the best, most optimal legal mean from all the existing volume of such means that is necessary in a particular life situation.

Thus, taking into account the foregoing, we conclude that professional legal assistance should be understood as the activity carried out by an attorney (on a paid or non-paid basis), which pursues the sole purpose of effectively implementing the rights, freedoms and legitimate interests of a person.

The provision of professional legal assistance must comply with certain principles, among which a special place is: the rule of law (in accordance with the Article 8 of the Constitution of Ukraine in Ukraine, the principle of the rule of law is recognized and in force, in which the norms of the Constitution are rules of direct action and appeal to the court to protect constitutional rights and freedoms of a person and a citizen are 
guaranteed directly on the basis of the Constitution of Ukraine. The provision of the right to professional legal assistance stipulated by the Article 59 of the Constitution of Ukraine is the responsibility of the state depending on the fixing of the relevant mechanisms for the implementation of this right in laws or other normative legal acts of Ukraine); legality (the provision of professional legal assistance in Ukraine is possible only on the principles stipulated by the Constitution, other normative legal acts of Ukraine, the international treaties in force, the consent to which the Verkhovna Rada of Ukraine has obligated) ${ }^{29}$; independence (any external influence, pressure or interference in the process of rendering professional legal assistance, in particular from the state and local authorities, their officials, political parties, as well as the influence of the individual interests of the subject of such assistance is prohibited) ${ }^{30}$; preventive (professional legal assistance promotes the legitimate exercise of one's rights and freedoms, as well as aims to prevent possible violations or illegal restrictions of human rights and freedoms) ${ }^{31}$; the inadmissibility of a conflict of interests (no conflict between the personal interests of the subject of the provision of professional legal assistance and one's professional rights and obligations); confidentiality (limited access of a certain circle of persons to information defined by law, or is personal data about an individual protected by the legislation on protection of personal data) ${ }^{32}$; quality (the state, guaranteeing everyone the right to professional legal assistance, establishes appropriate professional and other criteria for the entities that are entitled/obliged to provide this assistance, thus sharing the responsibility for the quality of such assistance), etc. ${ }^{33}$.

\footnotetext{
29 Закон України “Про безоплатну правову допомогу”. Науково-практичний коментар / за заг. ред. М. В. Оніщука. Київ: КП-Сервіс, 2012. С. 15.

${ }^{30}$ Правила адвокатської етики: затв. Звітно-виборним з’їдом адвокатів України 09.06.2017 p. URL: http://vkdka.org/pravila-advokatskoji-etiki-zatverdzheni-zvitno-vibornim-zjizdom-advokativ-ukrajini-2017

${ }^{31}$ Рішення Конституційного Суду України у справі за конституційним зверненням громадянина Голованя Ігоря Володимировича щодо офіційного тлумачення положень статті 59 Конституції України (справа про право на правову допомогу) від 30.09.2009 р. № 23-рп/2009. Офіиіийний вісник Украӥни. 2009. № 79. Ст. 62.

${ }^{32}$ Правила адвокатської етики: затв. Звітно-виборним з’їздом адвокатів України 09.06.2017 p. URL: http://vkdka.org/pravila-advokatskoji-etiki-zatverdzheni-zvitno-vibornim-zjizdom-advokativ-ukrajini-2017

33 Закон України "Про безоплатну правову допомогу". Науково-практичний коментар / за заг. ред. М. В. Оніщука. Київ: КП-Сервіс, 2012. С. 16.
} 


\section{The human right to professional legal assistance as part of the right to a fair trial and accessible justice}

The human right to professional legal assistance should be considered as part of the right to a fair trial and accessible justice, which in turn is an important aspect of the practical implementation of the rule of law ${ }^{34}$.

The right to a fair trial is enshrined in first paragraph of the Article 6 of the Convention for the Protection of Human Rights and Fundamental Freedoms (1950), which states that "in the determination of his civil rights and obligations or of any criminal charge against him, everyone is entitled to a fair and public hearing within a reasonable time by an independent and impartial tribunal established by law. Judgment shall be pronounced publicly but the press and public may be excluded from all or part of the trial in the interests of morals, public order or national security in a democratic society, where the interests of juveniles or the protection of the private life of the parties so require, or to the extent strictly necessary in the opinion of the court in special circumstances where publicity would prejudice the interests of justice". Besides, the Article 6, paragraph 3 (c) of this Convention contains provisions that "everyone charged with a criminal offence has the right to defend himself in person or through legal assistance of his own choosing or, if he has not sufficient means to pay for legal assistance, to be given it free when the interests of justice so require" 35 .

Article 10 of the Law of Ukraine "On the Judiciary and the Status of judges" of June 2, 2016, No. 1402-VIII, entitled "Professional Legal Assistance in the Realization of the Right to a Fair Court", duplicates the provisions of the Constitution of Ukraine regarding the right of a person to professional legal assistance ${ }^{36}$.

The concept of a fair trial contains criteria for assessing, first of all, the procedures for judicial review, that is, procedural justice. Any social institution, including the right, can not be fair without ensuring its availability, or the opportunity to take advantage of it, because the idea of

\footnotetext{
${ }^{34}$ Гомьен Д., Харрис Д., Зваак Л. Европейская конвенция о правах человека и Европейская социальная хартия: право и практика. Москва: МНИМП, 1998. С. 279.

${ }^{35}$ Convention for the Protection of Human Rights and Fundamental Freedoms (Rome, 4.XI.1950) as amended by Protocols Nos. 11 and 14, supplemented by Protocols Nos. 1, 4, 6, 7, 12, 13 and 16. URL: https://www.echr.coe.int/Documents/Convention_ENG.pdf

${ }^{36}$ Про судоустрій і статус суддів: Закон України від 02.06.2016 р. № 1402-VIII. Офіuіийний вісник України. 2016. № 56. Ст. 1935.
} 
free and equal distribution of social benefits is violated ${ }^{37}$. The scientists admit that the driving force for the formation of the "access to justice" movement was the problems associated with the implementation of the right to legal assistance, namely, the inability to receive it by poor people $^{38}$.

Ukrainian researcher V. Isakova notes that "the very existence in the legal system of rights raises the question of the possibility of their forced implementation, and in the event that a person does not have the possibility of free access to the instruments of such coercion, logic requires that a mechanism for legal assistance be created. Legal assistance in this case is one of the elements that can ensure the enforcement of rights, although, of course, not the only one. The right to legal assistance is a matter of such paramount importance that all other rights relating to a fair trial may be waived of any value if this right is not respected". Without the existence of a court, human rights and freedoms can not be adequately protected in the event that another person is threatened with subjective rights and freedoms. The basis of the modern concept of just or proper justice naturally forms the principle of free access to justice ${ }^{39}$.

Also, the right to professional legal assistance is an important element of the accessibility of justice, which is a necessary sign of the legal state. In this aspect V. Isakova said that "both judges, practicing lawyers and smart people are clear that in most cases ... people without a lawyer do not receive the same justice in quality as others and successfully removed from real access to the judicial system" 40 .

O. Ovcharenko considered the accessibility of justice as a principle of organization and activity of the judiciary, the essence of which is the absence of factual and legal obstacles to appealing to the court for the protection of one's rights. The content of justice is disclosed through a set of its elements: 1) legal (institutional and procedural): the territorial proximity of the court; openness of information about it; universal jurisdiction of the court; its competence; stability of the judicial system;

\footnotetext{
${ }^{37}$ Овчаренко О. М. Доступність правосуддя та гарантії його реалізації: монографія. Харків: Право, 2008. C. 23.

${ }^{38}$ Сакара Н. Ю. Проблема доступності правосуддя у цивільних справах: дис. ... канд. юрид. наук. Харків, 2006. С. 16.

${ }^{39}$ Ісакова В. М. Право на правову допомогу як елемент принципу доступності правосуддя. Форум права. 2012. № 4. С. 405.

${ }^{40}$ Ісакова В. М. Право на правову допомогу як елемент принципу доступності правосуддя. Форум права. 2012. № 4. С. 405.
} 
2) social: the need of citizens in resolving legal conflicts that arise in society; the level of development of the legal consciousness of society as a whole and individual citizens, which consists in legal awareness of the population and in the trust of citizens in court; the level of justice of the carriers of the judiciary (judges); 3) economic: the state's expenditure on the financing of the judiciary; expenses of the parties and other participants of the case, provided by procedural legislation; expenses of the state on providing access to the court of the poorest sections of the population $^{41}$.

Thus, the right to professional legal assistance is one aspect of access to justice and the right to a fair trial.

Taking into account the foregoing, one can conclude that the human right to professional legal assistance is guaranteed by the Constitution of Ukraine, other normative legal acts, the opportunity of the individual to receive (on a paid or free basis) assistance from an attorney, consisting of solving a problem legal situation in order to effectively provision one's rights, freedoms and legitimate interests.

Specific features of professional legal assistance are:

1) is a kind of professional activity carried out by an advocate;

2) provides for legal content in actions (services), in particular, provision of legal information and consultations, preparation of documents of a legal nature, representation of another person in a court, protection of the person from the criminal prosecution, etc., that may be relevant to a legal fact that generates, changes or terminates specific legal relationship;

3) may be provided on a paid or free basis;

4) is risky if it is provided on a paid basis (on a contractual basis) because the provision of professional legal assistance does not guarantee the receipt of a positive result in the case in favour of the client;

5) conforms to the principles of the rule of law, legality, independence, preventive, inadmissibility of a conflict of interests, confidentiality, quality, etc.

The human right to professional legal assistance, firstly, is the fundamental, inalienable right of everyone, which is a set of legal possibilities of an individual as a participant in legal relations, in order to

\footnotetext{
${ }^{41}$ Овчаренко О. М. Доступність правосуддя та гарантії його реалізації: монографія. Харків: Право, 2008. C. 13,74 .
} 
achieve the set legal goals, and secondly, it serves as a key constitutional guarantee for provision of other human rights (including the right to a fair trial) ${ }^{42}$. That's why, the human right to professional legal assistance is considered as having a dualistic legal nature.

\section{SUMMARY}

The article deals with the concept and legal nature of the right to professional legal assistance. In this aspect, the essence of professional legal assistance and its special features are disclosed.

It has been established that this right, firstly, is the fundamental, inalienable right of everyone, which is a set of legal possibilities of an individual as a participant in legal relations, in order to achieve the set legal goals, and secondly, it serves as a key constitutional guarantee for the provision of other human rights (including the right to fair trial). Particular attention is paid to the right to professional legal assistance as one of the aspects of access to justice and the right to a fair trial.

The article focuses on the fact that the provision of the right to professional legal assistance is not only a constitutional and legal duty of the state, but also observance of the international legal obligations undertaken by Ukraine in accordance with the provisions of international agreements in the field of human rights.

\section{REFERENCES}

1. Конституція України від 28.06.1996 p. № 254к/96-ВР. URL: http://zakon5.rada.gov.ua/laws/show/254\%D0\%BA/96$\%$ D0\%B2\%D1\%80.

2. Рішення Конституційного Суду України у справі за конституційним зверненням громадянина Голованя Ігоря Володимировича щодо офіційного тлумачення положень статті 59 Конституції України (справа про право на правову допомогу) від 30.09.2009 р. № 23-рп/2009. Офіиійний вісник Украӥни. 2009. № 79. Ст. 62.

3. Рішення Конституційного Суду України у справі за конституційним зверненням громадянина Солдатова Геннадія

\footnotetext{
42 Ісакова В. М. Право на правову допомогу: поняття, особливості, гарантії: автореф. дис. .... канд. юрид. наук. Харків, 2013. С. 14; Джуська А. В. Право на правову допомогу як гарантія конституційноправового статусу людини і громадянина. Право: історія, теорія, практика: матеріали між народ. наук.-практ. конф. (м. Херсон, 14-15 берез. 2014 р.). Херсон: Гельветика, 2014. С. 32.
} 
Івановича щодо офіційного тлумачення положень статті 59 Конституції України, статті 44 Кримінально-процесуального кодексу України, статей 268, 271 Кодексу України про адміністративні правопорушення (справа про право вільного вибору захисника) від 16.11.2000 p. № 13-рп/2000. Офіиійний вісник України. 2000. № 47. Ст. 109.

4. Пояснювальна записка від 26.01.2016 р. до проекту Закону України про внесення змін до Конституції України (щодо правосуддя) від 25.11.2015 p. № 3524. URL: http://w1.c1.rada.gov.ua/ pls/zweb2/webproc4_1?pf3511=57209.

5. Литовченко Л. А., Чуйко О. В. Поняття “право на правову допомогу" та "правова допомога" у контексті конституційного та цивільно-процесуального законодавства. Науковий вісник Дніпропетровського державного університету внутрішніх справ. 2011. № 4. C. 152-161.

6. Ісакова В. М. Право на правову допомогу: поняття, особливості, гарантії: автореф. дис. ... канд. юрид. наук. Харків, 2013. 19 c.

7. Панченко В. Ю. Юридическая помощь (вопросы общей теории): монография. Красноярск: Сиб. федер. ун-т, 2011. 279 с.

8. Basic Principles on the Role of Lawyers (adopted by the Eighth United Nations Congress on the Prevention of Crime and the Treatment of Offenders, Havana, Cuba 27 August to 7 September 1990). URL: https://www.ohchr.org/en/professionalinterest/pages/roleoflawyers.aspx

9. Resolution (78) 8 "On legal aid and advice" (adopted by the Committee of Ministers of the Council of Europe on 2 March 1978 at the 284th meeting of the Ministers' Deputies). URL: https://www.euromedjustice.eu/en/system/files/20090128115013_res\%2878\%298eCoE.pdf

10. Правова допомога: зарубіжний досвід та пропозиції для України / авт.-упоряд. О. А. Банчук, М. С. Демкова. Київ: Факт, 2004. $336 \mathrm{c.}$

11. Про адвокатуру та адвокатську діяльність: Закон України від 05.07.2012 p. № 5076-VI. Відомості Верховної Ради Украӥни. 2013. № 27. Ст. 282.

12. Мельниченко Р. Г. Конституционное право на юридическую помощь: автореф. дис. ... канд. юрид. наук. Волгоград, 2001. 23 с. 
13. Степанова С. В. Ефективна допомога захисника як складова конституційного права на професійну правничу допомогу та міжнародний стандарт права на справедливий суд. Юриспруденція у формуванні правової держави та громадянського суспільства: матеріали міжнарод. юрид. наук.-практ. Інтернет-конф. (06.10.2016 p.). URL: http://legalactivity.com.ua/index.php?option= com_content $\&$ view=article $\& \mathrm{id}=1332 \% 3 \mathrm{~A} 041016-20 \& \mathrm{catid}=161 \% 3 \mathrm{~A} 2-$ 1016\&Itemid=201\&lang $=$ ru.

14. Алексеев С. С. Восхождение к праву. Поиски и решения. Москва: Норма, 2001. 752 с.

15. Михайловская И. Б., Кузьминская Е. Ф., Мазаев Ю. Н. Юридическая помощь населению: потребности и возможности. Москва. 1995. 89 с.

16. Андрусів В. Г. Співвідношення забезпечення адвокатурою права на захист 3 наданням правової допомоги. Бюлетень Міністерства юстииї Украӥни. 2006. № 12 (62). С. 126-131.

17. Жалинский А. Э. Основы профессиональной деятельности юриста. Введение в специальность. Смоленск: Изд-во Смол. ун-та, 1995. $128 \mathrm{c}$.

18. Закон України "Про безоплатну правову допомогу". Науково-практичний коментар / за заг. ред. М. В. Оніщука. Київ: КП-Сервіс, 2012. 100 с.

19. Правила адвокатської етики: затв. Звітно-виборним з'їздом адвокатів України 09.06.2017 p. URL: http://vkdka.org/pravilaadvokatskoji-etiki-zatverdzheni-zvitno-vibornim-zjizdom-advokativukrajini-2017

20. Гомьен Д., Харрис Д., Зваак Л. Европейская конвенция о правах человека и Европейская социальная хартия: право и практика. Москва: МНИМП, 1998. 600 с.

21. Convention for the Protection of Human Rights and Fundamental Freedoms (Rome, 4.XI.1950) as amended by Protocols Nos. 11 and 14, supplemented by Protocols Nos. 1, 4, 6, 7, 12, 13 and 16. URL: https://www.echr.coe.int/Documents/Convention_ENG.pdf

22. Про судоустрій і статус суддів: Закон України від 02.06.2016 р. № 1402-VIII. Офіиіийний вісник України. 2016. № 56. Ст. 1935.

23. Овчаренко О. М. Доступність правосуддя та гарантії його реалізації: монографія. Харків: Право, 2008. 304 с. 
24. Сакара Н. Ю. Проблема доступності правосуддя у цивільних справах: дис. ... канд. юрид. наук. Харків, 2006. 209 с.

25. Ісакова В. М. Право на правову допомогу як елемент принципу доступності правосуддя. Форум права. 2012. № 4. С. 404-410.

26. Джуська А. В. Право на правову допомогу як гарантія конституційно-правового статусу людини і громадянина. Право: історія, теорія, практика: матеріали між народ. наук.-практ. конф. (м. Херсон, 14-15 берез. 2014 р.). Херсон: Гельветика, 2014. С. 30-32.

\section{Information about the author:} Dzhuska A. V.

$\mathrm{Ph} . \mathrm{D}$ in Law, Lecturer at the Department of Constitutional and International Law of the Educational and Scientific Humanitarian Institute of the V. I. Vernadsky Taurida National University 33, I. Kudri str., Kyiv, 02000, Ukraine 